University at Buffalo School of Law

Digital Commons @ University at Buffalo School of Law

1999

\title{
The African Human Rights Court: A Two-Legged Stool?
}

\author{
Makau Mutua \\ University at Buffalo School of Law
}

Follow this and additional works at: https://digitalcommons.law.buffalo.edu/journal_articles

Part of the Human Rights Law Commons

\section{Recommended Citation}

Makau Mutua, The African Human Rights Court: A Two-Legged Stool?, 21 Hum. Rts. Q. 342 (1999).

Available at: https://digitalcommons.law.buffalo.edu/journal_articles/567

Copyright (c) 1999 The Johns Hopkins University Press. This article was first published in Human Rights Quarterly 21.2 (1999), 342-363. Reprinted with permission by Johns Hopkins University Press.

\section{IN COPYRIGHT}

This Article is brought to you for free and open access by the Faculty Scholarship at Digital Commons @ University at Buffalo School of Law. It has been accepted for inclusion in Journal Articles by an authorized administrator of Digital Commons @ University at Buffalo School of Law. For more information, please contact lawscholar@buffalo.edu. 


\title{
The African Human Rights Court: A Two-Legged Stool?
}

\author{
Makau Mutua*
}

\section{INTRODUCTION}

The adoption in June 1998 of the Protocol to the African Charter on Human and Peoples' Rights on the Establishment of an African Court on Human and Peoples' Rights (African Human Rights Court)' by the Assembly of Heads of State and Government of the Organization of African Unity (OAU) is potentially an important step in the protection of human rights in the African continental system. ${ }^{2}$ The African Human Rights Court would complement ${ }^{3}$

* Makau Mutua is a Visiting Professor, Harvard Law School, Spring 1999 and Associate Professor, SUNY-Buffalo School of Law. He is Director, Human Rights Center, SUNY-Buffalo and Chair of the Kenya Human Rights Commission. The author received his S.J.D. in 1987 from Harvard Law School, an LL.M. in 1985 from Harvard Law School, an LL.M. in 1984 from University of Dar-es-salaam; and his LL.B. in 1983 from University of Dar-es-salaam.

1. Draft Protocol to the African Charter on Human and Peoples' Rights on the Establishment of an African Court on Human and Peoples' Rights by the Assembly of Heads of State and Government of the Organization of African Unity, Conference of Ministers/ Attorneys General on the Establishment of an African Court on Human and Peoples' Rights, OAU/LEG/MIN/AFCHPR/PROT.(1)Rev.2 (1997) [hereinafter Protocol].

2. See Gino J. Naldi \& Konstantinos Magliveras, Reinforcing the African System of Human Rights: The Protocol on the Establishment of a Regional Court of Human and Peoples' Rights, 16 Neth. Q. Hum. Rrs. 431 (1998); 2 U. OlI Umozurike, The African Charter on Human and Peoples' Rights 92-93 (1997); Pursuit for Peace Remains Major Task of Africa: Salim, XINHUA News AgenCY, 8 June 1998, available in LEXIS, News Library, CURNWS File; International Conference on Human Rights Commission Opens in Addis, XINHUA News Acency, 18 May 1998, available in LEXIS, News Library, CURNWS File. As expected, the Draft Protocol was adopted by the 1998 OAU summit in Ouagadougou, Burkina Faso. See Ghion Hagos, Africa at Large; Conference Adopts Protocol on African Human Rights Court, Afr. News, 13 Dec. 1997, available in LEXIS, News Library, CURNWS File; Ghion Hagos, Africa at Large; Africa Human Rights Court on the Cards, Afr. News, 11 Dec. 1997, available in LEXIS, News Library, CURNWS File.

3. The Protocol is now open for signature following its adoption by the OAU. It shall come into force thirty days after ratification by fifteen OAU member states, a number that should be reached quickly. See Protocol, supra note 1, art. 34 . The Protocol states in the preamble that the African Human Rights Court shall "complement and reinforce the 
the African Commission on Human and Peoples' Rights (African Commission), the body that has exercised continental oversight over human rights since 1987.4 The Protocol suggests that the African Human Rights Court will make the promotion and the protection of human rights within the regional system more effective. ${ }^{5}$ However the mere addition of a court, although a significant development, is unlikely by itself to address sufficiently the normative and structural weaknesses that have plagued the African human rights system since its inception.

The modern African state, which in many respects is colonial to its core, has been such an egregious human rights violator that skepticism about its ability to create an effective regional human rights system is appropriate. ${ }^{6}$ Although the African Charter makes a significant contribution to the human rights corpus, it creates an ineffectual enforcement system. Its most notable contributions are the codification of the three "generations" of rights, including the innovative concept of peoples' rights, ${ }^{7}$ and the imposition of duties on individuals. ${ }^{8}$ But many commentators have focused on the

functions of the African Commission on Human and Peoples' Rights." Protocol, supra note 1, pmbl. The Protocol continues to clarify and emphasize that the African Human Rights Court shall "complement the protective mandate of the African Commission on Human and Peoples' Rights." Protocol, supra note 1, art. 2.

4. The African Commission on Human and Peoples' Rights (African Commission) is the supervisory organ for the implementation of the African Charter on Human and Peoples' Rights. African Charter on Human and Peoples' Rights, adopted 26 June 1981, O.A.U. Doc. CAB/LEG/67/3/Rev.5 (entered into force 21 Oct. 1986), reprinted in 21 I.L.M. 58 (1982) Ihereinafter African Charter]. The African Charter is also known as the Banjul Charter.

5. See Protocol, supra note 1 , pmbl.

6. For discussions and analyses of the colonial imprint on the African post-colonial state, See Mahmood Mamdani, Cittzen ano Subject: Contemporary Africa and the Legacy of Late Colonialism (1996); Crawford Young, The Heritage of Colonialism, in Africa IN Worlo Poumics 19 (John W. Harbeson \& Donald Rothschild eds., 1991); Robert H. Jackson, Juridical Statehood in Sub-Saharan Africa, 46 J. INT'L Aff. 1 (1992); Ali A. Mazrui, The African State as a Political Refugee: Institutional Collapse and Human Displacement, 7 INT'L J. Refucee L. 21 (1995); and Makau wa Mutua, Why Redraw the Map of Africa: A Moral and Legal Inquiry, $16 \mathrm{MiCH}$. J. INT'L L. 1113 (1995). Discussing Africa's colonial legacy, one author notes that the "most obvious and powerful expressions of the continued African conceptual reliance on European political forms are the African states themselves. The states are direct and uncritical successors of the colonies." Art Hansen, African Refugees: Defining and Defending Their Human Rights, in Human RiGHS AND GovernanCE in Africa 139, 161 (Ronald Cohen et al. eds., 1993).

7. Peoples' rights, along with rights to environment and group rights, are known as thirdgeneration rights. Civil and political rights are considered first-generation rights, and social, economic, and cultural rights are considered second-generation rights.

8. On duties on the individual, see African Charter, supra note 4, at arts. 27-29. For a discussion of the concept of duties in human rights discourse and the African Charter, see Makau wa Mutua, The Banjul Charter and the African Cultural Fingerprint: An Evaluation of the Language of Duties, 35 VA. J. INT'L L. 339 (1995). See also Obinna Okere, The Protection of Human Rights in Africa and the African Charter on Human and Peoples' Rights: A Comparative Analysis with the European and American Systems, 6 Hum. RTs. Q. 141 (1984); Josiah A.M. Cobbah, African Values and the Human Rights Debate: An African Perspective, 9 Hum. Rrs. Q. 309 (1987). 
weaknesses in the African system. These include the "clawback" clauses in the African Charter, the potential abuse of the language of duties, and the absence of an effective protection mandate for the African Commission. ${ }^{9}$

Recent changes in the African states, particularly those changes responding to demands for more open political societies, may augur well for the protection of civil and political rights. ${ }^{10}$ Emergent democracies such as Namibia, Malawi, Benin, South Africa, Tanzania, and Mali are more inclined than their predecessors to respect human rights at home and to agree to a more viable regional system. In this context, the proposed African Human Rights Court would operate in a less hostile or cynical environment than the environment that determined and sharply limited the powers and effectiveness of the African Commission. In addition, the 1994 Rwandese genocide and the recent atrocities in Nigeria, Liberia, Somalia, Ethiopia, Sudan, Sierra Leone, Burundi, the Republic of the Congo, and the Democratic Republic of the Congo have further illuminated the need for stronger domestic and regional guarantees for human rights. In fact, at no time in recent African history have the conditions for the creation of an effective regional human rights system been more favorable.

This article critically evaluates the proposed African Human Rights Court and assesses its potential impact on the African human rights system. It probes the powers of the Court and asks whether a clear and mutually reinforcing division of labor between it and the African Commission could be developed to more effectively promote and protect human rights on the continent. For example, should the mandate of the African Commission be limited primarily to promotional activities, and the African Human Rights Court exclusively given the protective function? What relationship should the Court have to the African Commission?

In sum, this article explores the effect that the African Human Rights Court is likely to have in three principal areas. First, it examines the role of the African Human Rights Court in the development of the law of the African Charter and other relevant human rights instruments. Second, it addresses ways in which the Court can fill the lacunae left by the African

9. For discussions of these problems, see Richard Gittleman, The African Charter on Human and Peoples' Rights: A Legal Analysis, 22 VA. J. INT'L L. 667 (1982); Richard Gittleman, The African Commission on Human and Peoples' Rights: Prospects and Procedures, in Guide to International Human Rights Practice 153 (Hurst Hannum ed., 1984); Cees Flinterman \& Evelyn Ankumah, The African Charter on Human and Peoples' Rights, in Guide to International Human Richts Practice 159 (Hurst Hannum ed., 2d ed. 1992).

10. See Makau wa Mutua, African Renaissance, N.Y. Times, 11 May 1991, at L23 (describing the demands by Africans for political democracy); Human Rights Watch, HUMAN Richts WATCH WORLD REPORT 1993, at 6-9 (1992) (reporting Africa's political upheavals, including those related to demands for political reforms and democracy). 
Commission and alleviate some of its weaknesses. Finally, it discusses ways in which the Court can penetrate the legal and political cultures of African states to inspire, encourage, and ensure the internalization of human rights.

\section{AMBIGUITY AND ANEMIA: THE STATUS QUO}

The African human rights system is anchored in the African Charter, an instrument that is largely promotional with an ambiguous protective function and no credible enforcement mechanism. This is hardly surprising because virtually no African state, with the exceptions of the Gambia, Senegal, and Botswana could even boast of a nominal democracy in 1981, the year that the OAU adopted the African Charter. " Hopes by observers of the African Commission that its commissioners would robustly construe the Charter's powers to alleviate its weaknesses have largely gone unrealized. With respect to specific functions, and to its performance in general, the African Commission has been a disappointment. This section discusses the architecture of the African Commission and outlines its basic strengths and weaknesses.

The basic functions of the African Commission are both promotional and protective. ${ }^{12}$ The promotional function, which the Charter emphasizes, ${ }^{13}$ includes research and dissemination of information through workshops and symposia, the encouragement of national and local human rights institutions, the formulation of principles to address legal problems in human rights, and cooperation with African and international human rights institutions. ${ }^{14}$ The Commission is empowered to interpret the Charter at the request of a state party, the OAU, or any organization recognized by the OAU..$^{15}$ In contrast, the provision relating to the protective function is quite terse. It provides, without elaborating, only that the Commission shall "[e]nsure the protection of human and peoples' rights" in the Charter. ${ }^{16}$

More concretely, the African Charter charges the Commission with three principal functions: examining state reports, ${ }^{17}$ considering communi-

11. See Makau wa Mutua, The African Human Rights System in a Comparative Perspective, African Comalission on Human ano Peoples' Rights, 3 Rev. Afr. Comm'n on Hum. \& Peoples' RTs. 5 (1993).

12. See African Charter, supra note 4 , art. 45 , which sets out the functions of the African Commission.

13. Id. (providing largely for promotional, not protective, functions of the Commission).

14. See id. art. $45(1)$.

15. See id. art. 45(3). This role, which allows the Commission to interpret the Charter, is potentially one of the areas that the commissioners could seize upon to expound and clarify the Charter.

16. Id. art. 45(2).

17. See id. art. 62. States parties must submit, every two years, a report on the legislative and other measures taken to give effect to rights in the African Charter. Id. 
cations alleging violations, ${ }^{18}$ and expounding the African Charter. ${ }^{19}$ These functions follow the general script of other regional as well as universal human rights bodies.$^{20}$ In particular, the Commission seems to have drawn substantially from the procedures and experiences of the UN Human Rights Committee. ${ }^{21}$ Its Rules of Procedure, ${ }^{22}$ which provide for process before the Commission, and the Reporting Guidelines, ${ }^{23}$ which specify the form and content of state reports, mirror the lessons of other human rights bodies. The Guidelines were supplemented by General Directives, an unpublished document that was sent to foreign ministers of state parties in $1990 .{ }^{24}$ The Directives are just a precis of the Guidelines.

The Commission's primary protective function, that of considering complaints filed by individual victims as well as nongovernmental organizations (NGOs), ${ }^{25}$ has a large potential that thus far has not been realized. For example, the Charter places no restriction as to who may file a communication. This lack of restriction creates an opening that allows any individual, groups, or NGOs, whether or not they are the direct victims of the alleged violation, to lodge a petition. ${ }^{26}$ However, communications ${ }^{27}$ can only be

18. See id. arts. 47,55 . The Charter permits two types of communications: from individuals, NGOs, and groups, on the one hand, and inter-state communications, on the other. The latter has never been invoked and will not concern this article. $I d$.

19. See id. art. 45(3).

20. See Philip Alston, Critical Appraisal of the UN Human Rights Regime, in THE UNITED Nations and Human Rights: A Crimcal Appraisal 1 (Philip Alston ed., 1992). See generally Thomas Buergenthal, International. Human Rights: In a Nutshell 21-247 (2d. ed. 1995) (describing UN Charter-based and treaty-based human rights instruments and bodies, as well as the African, Inter-American, and European human rights systems).

21. The Human Rights Committee is the treaty body that oversees the implementation of the International Covenant on Civil and Political Rights (ICCPR). International Covenant on Civil and Political Rights, adopted 16 Dec. 1966, G.A. Res. 2200 (XXI), U.N. GAOR, 21st Sess., Supp. No. 16, at 52, U.N. Doc. A/6316 (1966), 999 U.N.T.S. 171 (entered into force 23 Mar. 1976).

22. Revised Rules of Procedure of the African Commission on Human and Peoples' Rights, adopted 6 Oct. 1995, reprinted in 18 Hum. RTs. L.J. 154 (1997) thereinafter Rules of Procedure].

23. Guidelines for National Periodic Reports, Second Annual Activity Report of the African Commission on Human and Peoples' Rights, Annex III, AFR/COM/HPR.5(VI)(1989) [hereinafter Reporting Guidelines].

24. See Astrid Danielsen, The State Reporting Procedure Under the African Charter 51-52 (1994); Evelyn A. Ankumah, The African Commission on Human and Peoples' Rights: Practice and Procedures 82-83 (1996).

25. The African Charter requires that the Commission "cooperate" with African and international NGOs in its work. African Charter, supra note 4, art. 45(1)(a) \& (c). Thus the Commission grants human rights NGOs observer status which allows their representatives to participate in the public sessions of the Commission. See Rules of Procedure, supra note 22, rule 75.

26. See African Charter, supra note 4 , art. 55.

27. "Communication" is usually used as a euphemism for "complaint" by the international human rights bodies. 
considered by the Commission if they meet certain conditions, including the requirements that they: indicate their authors, even if anonymity is requested; are not written in a language that is insulting or disparaging to the state or the OAU; are not incompatible with the OAU Charter and the African Charter; are not based exclusively on media reports; are sent after the petitioner exhausts local remedies, unless these are obviously unduly prolonged; are submitted within a reasonable time after local remedies are exhausted; and do not deal with a matter that has already been settled by the states concerned in accordance with international instruments. ${ }^{28}$

Although the Charter does not explicitly require it, communications are considered in private or closed sessions. ${ }^{29}$ If the Commission determines that one or more communications "relate to special cases which reveal the existence of a series of serious or massive violations ${ }^{\prime 30}$ of human rights, it must draw the attention of the OAU to such a situation and, presumably, conduct an on-site investigation. In the case of an emergency, the Commission must inform the Chair of the OAU and request an in-depth study, which most likely would call for on-site fact-finding. ${ }^{31}$ The Commission's power to conduct such investigations is clearly authorized by the Charter, which empowers it to "resort to any appropriate method of investigation." ${ }^{\text {"32 }}$ This provision had remained a dead letter until 1995 when the Commission, with the assistance of the OAU Secretary General, secured the agreement of Senegal and Togo for field investigations. ${ }^{33}$ Until this point however, the commissioners had been reluctant to claim these powers. ${ }^{34}$

The Commission's formula for considering individual communications closely mirrors that of the UN Human Rights Committee $(H R C){ }^{35}$ In a

28. See African Charter, supra note 4, art. 56 .

29. See Rules of Procedure, supra note 22, rule 106. The Commission, which makes its own rules of procedure, may justify closed sessions for communications under Article 59 of the Charter which provides, in part, that "[a]ll measures taken within the provisions of the present Chapter [sic] shall remain confidential" until the OAU decides otherwise. African Charter, supra note 4, art. 59. But this provision is overbroad and vague. A literal interpretation of "all measures" would be absurd. Perhaps the Commission could open at least part, if not all, of the communications processes to the public.

30. African Charter, supra note 4 , art. 58(1) \& (2).

31. See id. art. 58(3).

32. Id. art. 46.

33. See Final Communique: 17th Ordinary Session of the African Commission on Human and Peoples' Rights, 12-22 Mar. 1995, Lome, Togo, available in <http://www1.umn.edu/ humanrts/africa/achpr17f.html>; ANKUмaH, supra note 24, at 42.

34. Because the Commission did not carry out investigations from 1987 until 1995, it seems to have been reluctant to do so.

35. See Optional Protocol to the International Covenant on Civil and Political Rights, adopted 16 Dec. 1966, G.A. Res. 2200A (XXI), U.N. GAOR, 21st Sess., Supp. No. 16, at 59, U.N. Doc. AV6316 (1966), 999 U.N.T.S. 171 (entered into force 23 Mar. 1976), reprinted in 6 I.L.M. 383 (1967) (detailing the HRC's formula for considering individual communications). 
format similar to that of the HRC, the Commission arranges its decisions into sections dealing with facts, arguments, admissibility of evidence, merits of the case, and the final conclusion. However, each of these sections is scant in both substance and reasoning. For example, in Constitutional Rights Project $v$. Nigeria, ${ }^{36}$ a petition challenging a death penalty that was imposed in violation of due process protections, the Commission adopted a scripted presentation, "declared" a violation of the Charter provisions, and "recommended" that Nigeria free the petitioners. ${ }^{37}$ Likewise, in another petition, Civil Liberties Organization v. Nigeria, ${ }^{38}$ the Commission cursorily found that the government enacted laws, in violation of the African Charter, to abridge due process rights and undermine the independence of the judiciary. However, it is fair to say that the communications procedure has come a long way since the early days. A predictable tradition of more fully considering petitions is slowly evolving.

A comparison of the decisions over the years shows that while room remains for considerable improvement, the quality of the Commission's reasoning and decision making has continued to evolve positively. In the past two years, the decisions of the Commission have been more substantive and elaborate on the issues of law and fact that are raised in and considered by communications. ${ }^{39}$

Nevertheless, despite signs of progress, the decisions referred to here, and others before them, are formulaic. They do not reference jurisprudence from national and international tribunals, nor do they fire the imagination. They are non-binding and attract little, if any, attention from governments and the human rights community. In the past, this lack of publicity could be attributed to the fact that the Commission prohibited the publication of its decisions. However, as explained by two human rights advocates, the African Commission has revised its strict interpretation of Article 59, which was formerly understood to prohibit the publication of communications:

This changed with the Seventh Activity Report of the Commission, adopted by the Assembly in June 1994. For the first time, this report made available information on the first fifty-two communications decided by the Commission. The information disclosed includes a summary of the parties to the communication, the factual background, and the Commission's summary decision. With

36. Communication 60/91, Afr. Comm'n Hum. Peoples' Rts., AHG/Res. 240 (XXXI)(1995), reprinted in 18 Hum. RTs. L.J. 28 (1997).

37. See id.

38. Communication 129/94, Afr. Comm'n Hum. Peoples' Rts., AHG/Res.250 (XXXII)(1996), reprinted in 18 Hum. RTs. L.J. 35, 36 (1997).

39. Chidi Anselm Odinkalu \& Camilla Christensen, The African Commission on Human and Peoples' Rights: The Development of its Non-State Communication Procedures, 20 Hum. Ris. Q. 235, 277 (1998) (footnotes omitted). 
the adoption of the Commission's Eighth and Ninth Annual Activity Reports, the Commission went a step further and issued full texts of its final decisions. ${ }^{40}$

Now the decisions may be published but the Commission must first obtain permission from the OAU Assembly of Heads of State and Government. ${ }^{41}$

Although the Commission's decision-making procedure appears quasijudicial, the Commission sees its principal objective as creating a dialogue between the parties, leading to the amicable settlement of the dispute in question. ${ }^{42}$ In any case, neither the Charter nor the Commission provides for enforceable remedies or a mechanism for encouraging and tracking state compliance with decisions. Thus, to many victims, the Commission's findings are too remote if not virtually meaningless. ${ }^{43}$

In addition to, and emblematic of, the Charter and the Commission's lack of enforcement mechanisms is the state reporting procedure that is required by the Charter. ${ }^{44}$ The Charter tersely provides that every two years, states shall submit a "report on the legislative or other measures taken with a view to giving effect to the rights and freedoms" enumerated in it. ${ }^{45}$ However, the Charter does not say to what body the reports are to be submitted, whether, how, and with what goal the reports should be evaluated, and what action should be taken after such evaluation. The Commission, not surprisingly, has filled in these gaps by borrowing heavily from other treaty bodies. ${ }^{46}$ Unfortunately, it has mimicked both the good and the bad in those bodies.

The Reporting Guidelines, which are detailed, are supposed to guide states in the preparation of their reports. In particular, the Guidelines specify both the form and content of reports. ${ }^{47}$ Thus reports must describe in detail

40. Id. at 278.

41. The Charter provides that all "measures taken within the provisions of the present Charter shall remain confidential until such a time as the Assembly of Heads of State and Government shall otherwise decide." African Charter, supra note 4, art. 59(1).

42. See Communications 16/88, 17/88, 18/88 Comite Culturel pour la Democratie au Benin, Hilaire Badjogoume, El Hadj Boubacare Diawara v. Benin (merits), Afr. Comm'n Hum. Peoples' Rts., II 35 (1994), reprinted in Odinkalu \& Christensen, supra note 36, at 244 n.51 (noting, inter alia, that "[i]t is the primary objective of the Commission in the Communications procedure to initiate a dialogue between the parties which will result in an amicable settlement to the satisfaction of both and which remedies the prejudice complained of").

43. See African Societr of International and Comparative Law, Report on the 16th Session of the African Conmission on Human and Peoples' Richts 62-83 (1996) for more communications by the Commission. For a very thoughtful analysis of the communications procedure before the African Commission, see Odinkalu \& Christensen, supra note 36.

44. African Charter, supra note 4 , art. 62.

45. Id.

46. See Felice D. Gaer, First Fruits: Reporting By States Under the African Charter on Human and Peoples' Rights, 10 Netr. Q. Hum. RTs. 29 (1992), for an evaluation of the 47. Id. initial state reporting under the African Charter. 
the legislative regime as well as the actual application and protection of specific human rights. ${ }^{48}$ In reality, however, many of the reports submitted thus far have been woefully inadequate on both counts..$^{49}$ For example, the initial report of Ghana was only a scant five pages. ${ }^{50}$ Similarly, Egypt's report, although a voluminous fifty pages, only described abstractly some legislation without commentary on the state of human rights conditions on the ground. ${ }^{51}$

Once submitted, reports are examined in public. State representatives and the commissioners engage in "constructive dialogue" to assist and encourage states to implement the Charter. After considering a report, the Commission communicates its comments and general observations to the state in question. ${ }^{52}$ However, although the Charter came into force in 1987, the majority of state parties have not submitted their reports, and the Commission has been powerless to force compliance. ${ }^{53}$ Thus, the reporting process seems to have yielded very little so far, as many of the state representatives have appeared either incompetent or ill-prepared.5.4 In addition to the fact that states do not seem to take the reporting process seriously, the comments and observations of the Commission on the few state reports that have been submitted have not had any discernable effect on those states.

However, the African Commission has taken some steps that have the potential to increase its impact on states. For example, one of the Commission's members has been appointed as a Special Rapporteur on Summary and Extra-judicial Executions..$^{55}$ This appointment is potentially significant if the office is used to investigate, report, and facilitate dialogue with states. ${ }^{56}$ Additionally, the Commission's country-specific and thematic resolutions raise the Commission's visibility and engage states directly. For example, one Commission resolution called on Sudan to allow detainees access to lawyers and doctors and asked the government to support negotiations for the settlement of the conflict with the south. ${ }^{57}$ Another

48. See id.

49. See generally ANKUMAH, supra note 24 , at $79-110$.

50. See id. at $91-92$.

51. See id.

52. See Rules of Procedure, supra note 22, rules 81-87.

53. See Mohamed Komeja, The African System of Human and Peoples' Rights: an Annotated Bibliography, 3 E. Afr. J. PeAce \& Hum. Rts. 262, 274-75 (1996).

54. See AnкUMAн, supra note 24 , at 99.

55. See Rachel Murray, Report on the 1996 Sessions of the African Commission on Human and Peoples' Rights, 19th and 20th Ordinary Sessions, 26 March-4 April, and 21-31 October 1996, 18 Hum. RTs. L.J. 16, 18 (1997).

56. See id.

57. See African Society of International and Comparative Law, supra note 40, at 89-90. 
Commission resolution ${ }^{58}$ urged African states to respect the rights of prisoners and to ratify the Convention Against Torture and Other Cruel, Inhuman or Degrading Treatment..$^{59}$ However small and tentative, these are steps in the right direction. Perhaps the African Human Rights Court will help clarify the roles and functions of the Commission and thereby embolden it.

\section{THE RATIONALE FOR A HUMAN RIGHTS COURT}

Both the European and the Inter-American human rights systems give the impression that a human rights court is an essential, if not indispensable, component of an effective regime for the protection of human rights. Norms prescribing state conduct are not meaningful unless they are anchored in functioning and effective institutions. In the case of the African regional system, this truism merits special attention because both the norms in the African Charter and the African Commission itself have been regarded as weak and ineffectual-hence the push for a human rights court, an institution that would correct some of the more glaring failures of the African system.

There are two possible polar views on the creation of an African Human Rights Court. One view holds that a human rights court must be established as soon as possible to salvage the entire system from its near-total irrelevance and obscurity. ${ }^{60}$ According to this view, the deficiencies of the African system-both normative and institutional-are so crippling that only an effective human rights court can jump-start the process of its redemption. ${ }^{61}$ The Court is here seen as a way to put some teeth and bite into the system in order to restrain states effectively.

The other view is gradualist and sees the work of the African system as primarily promotional and not adjudicative. ${ }^{62}$ According to the gradualist view, the major problem in Africa is the lack of awareness by the general populace of its rights and the processes for vindicating those rights. ${ }^{63}$ Proponents argue that the regional system must therefore first educate the

58. See id. at 95.

59. Convention Against Torture and Other Cruel, Inhuman or Degrading Treatment or Punishment, adopted 10 Dec. 1984, G.A. Res. 39/46, U.N. GAOR 39th Sess., Supp. No. 51, U.N. Doc. A/39/51 (1985) (entered into force 26 June 1987), reprinted in 23 I.L.M. 1027 (1984), substantive changes noted in 24 I.L.M. 535 (1985).

60. See Mutua, supra note 10, at 10; Komeja, supra note 51 , at 277.

61. See Mutua, supra note 10 , at 10.

62. See ANkUmah, supra note 24, at 194-95.

63. See id. 
public by promoting human rights. ${ }^{64}$ The task of protection, which would include a human rights court, is seen here as less urgent. ${ }^{65}$ Critics argue that a court might be paralyzed by the same problems that have beset the African Commission. ${ }^{66}$ They therefore urge that the African Commission be strengthened instead of dissipating scarce resources to create another, possibly impotent institution. ${ }^{67}$

In the past several years, the gradualist view has given way to the proponents of a human rights court. It had become clear by the mid-1990s, even to pro-establishment figures, that the African system was a disappointment, if not an embarrassment for the continent. In 1994, the conservative OAU Assembly of Heads of State and Government asked its Secretary General to call a meeting of government experts to "ponder in conjunction with the African Commission on Human and Peoples' Rights over the means to enhance the efficiency of the Commission in considering particularly the establishment of an African Court on Human and Peoples' Rights. ${ }^{\prime 68}$

Events moved speedily in the next several years. In September 1995, a draft document on an African human rights court was produced by a meeting of experts organized in Cape Town, South Africa by the OAU Secretariat in collaboration with the African Commission and the International Commission of Jurists. ${ }^{69}$ Later that month, an OAU meeting of governmental legal experts produced the Cape Town Draft of the draft protocol for a human rights court. ${ }^{70}$ After several rounds of meetings and more drafts, the Draft Protocol was adopted by the conference of OAU Ministers of Justice/Attorneys General in December 1997. The OAU Council of Ministers adopted the Draft Protocol in February $1998,{ }^{71}$ and the OAU Assembly gave its final blessing in June $1998,{ }^{72}$ opening the Protocol for signature by OAU member states.

The consensus among government officials, NGOs, and academics on the need for a human rights court in the African regional system has steadily

64. See id.

65. See id.

66. See id.

67. See id. at 195.

68. Report of Government Experts Meeting, AHG/Res 230(xxx), 30th Ordinary Session of the Assembly of Heads of State and Government, Tunis, Tunisia, June 1994, cited in Ibrahim Ali Badawi El-Sheikh, Draft Protocol to the African Charter on Human and Peoples' Rights on the Establishment of an African Court on Human and Peoples' Rights: Introductory Note, 9 Afr. J. INT'L \& Comp. L. 943, 943 n.1 (1997).

69. See id. at 944 .

70. See Report of Government Experts Meeting on the Establishment of an African Court of Human and Peoples' Rights, September 6-12, 1995, Cape Town, South Africa, OAU/ LEG/EXP/AFCHPR/RPT(1)Rev.1, cited in id. at 944 n.2.

71. See International Conference on Human Rights Commission Opens in Addis, supra note 2.

72. See Pursuit for Peace Remains Major Task of Africa: Salim, supra note 2. 
gained momentum. This realization is indicative of the shortcomings that currently plague the African system. While the push for the Court is not a repudiation of the African Commission, it is an acknowledgment of its general ineffectiveness. The hope appears to be that a court will strengthen the regional system and aid it in realizing its promise. But that will not happen unless the Court avoids the pitfalls that have trapped the African Commission.

The presence of other regional human rights courts in the Americas and Europe has given impetus to the African initiative and advanced the idea within the modern African state that its conduct toward its own citizens is no longer an internal, domestic matter. In turn, the establishment of the African Human Rights Court will help to promote international human rights in other regions of the world. For example, in Asia, where states have been more resistant to the application and internalization of the human rights corpus-and where as of yet there is no regional human rights system - that resistance is bound to come under increasing attack by NGOs due to the establishment of a human rights court in Africa. The regional supervision of a state's internal conduct toward its nationals is quickly becoming a reality. So too is the recognition that human rights are "a basic requirement in any society and a pre-requisite for human progress and development..$^{\prime \prime 3}$

The African Human Rights Court is a potentially significant development in the protection of rights on a continent that has been plagued with serious human rights violations since colonial rule. The problems of the African human rights system ${ }^{74}$ including the normative weaknesses in the African Charter and the general impotence of its implementing body, the African Commission, may now be addressed effectively and resolved by the establishment of this new adjudicatory body.

\section{THE ANATOMY OF THE AFRICAN HUMAN RIGHTS COURT}

The function of the African Human Rights Court would be protective, and would seek to complement the work of the African Commission, which is

73. Talks Open in Addis on Establishing African Human Rights Court, DeutsChe PresseAGENTUR, 12 Dec. 1997, available in LEXIS, News Library, CURNWS File (quoting Salim Ahmed Salim, the OAU Secretary General, at the adoption of the Draft Protocol in December 1997).

74. For analyses of some normative and structural problems of the African human rights system, see Gittleman, supra note 9; Flinterman \& Ankumah, supra note 9; Olusola Ojo \& Amadu Sessay, The OAU and Human Rights: Prospects for the 1980s and Beyond, 8 Hum. RTs. Q. 89 (1986); and ANKUMaн, supra note 24. 
basically promotional. ${ }^{75}$ Although the African Commission's mandate includes the protective functions of state reporting ${ }^{76}$ and the consideration of communications, ${ }^{77}$ promotional activities have been the centerpiece of its operations. ${ }^{78}$ Commentators agree that the Commission's state reporting and communications procedures have been disappointing, partly due to the lack of power and textual clarity of purpose for those functions. ${ }^{79}$ Can the African Human Rights Court cure these problems?

In order to entrench itself as a protector of international human rights, it is important that the Court's jurisdiction not be circumscribed or limited to cases or disputes that arise out of the African Charter. ${ }^{80}$ The Protocol provides that actions may be brought before the Court on the basis of any instrument, including international human rights treaties, which has been ratified by the state party in question. ${ }^{81}$ Furthermore, according to the Protocol, the Court can apply as sources of law any relevant human rights instrument ratified by the state, in addition to the African Charter. ${ }^{82}$ The Court will be empowered to decide if it has jurisdiction in the event of a dispute. ${ }^{83}$ The Court may exercise both contentious and conciliatory jurisdiction. ${ }^{84}$ It also will have advisory jurisdiction through which it may issue advisory opinions on "any legal matter relating to the Charter or any other relevant human rights instruments." ${ }^{15}$ Such an opinion may be requested by a wide variety of entities including a member state of the $\mathrm{OAU}$, the OAU or any of its organs, or even an African NGO, provided it is recognized by the OAU..$^{86}$

75. The Protocol realizes this contrast-in essence the weaknesses and the incompleteness of the African Commission-when its states in its preamble that the African Human Rights Court will "complement and reinforce the functions of the African Commission on Human and Peoples' Rights." Protocol, supra note 1, pmbl. The Protocol adds that the African Human Rights Court shall "complement the protective mandate of the African Commission." Id. art. 2.

76. See African Charter, supra note 4 , art. 62.

77. See id. at arts. 55, 56. These include state-to-state and "other" communications, which could come from individuals, groups, and organizations. $I d$.

78. See id. art. 45. The principal activities of the African Charter, which are promotional, are to collect documents, undertake studies, organize seminars, disseminate information, encourage national and local institutions concerned with human rights, formulate principles to resolve human rights problems, and interpret the African Charter. Id.

79. See, e.g., Mutua, supra note 8; Henry J. Steiner \& Phillip Alston, International Human Rights in Context: Law, Poumits, Morals 700-704 (1996).

80. See Protocol, supra note 1, art. 3(1) (extending the Court's jurisdiction to the African Charter "and any other relevant Human Rights instrument ...").

81. Id.

82. Id. art. 7.

83. See id. art. 3(2).

84. Id. art. 9 Article 9 allows the court to attempt the "amicable settlement" of disputes. Id.

85. Id. art. $4(1)$.

86. See id. 
One serious shortcoming of the proposed African Human Rights Court is the limitation of access placed by the Draft Protocol on individuals and NGOs. The Protocol provides for two types of access to the Court: automatic and optional. The African Commission, state parties, and African intergovernmental organizations enjoy unfettered or "automatic" access to the Court once a state ratifies the Draft Protocol. ${ }^{87}$ In stark contrast, individuals and NGOs cannot bring a suit against a state unless two conditions are met. First, the Court will have discretion to grant or deny such access. ${ }^{88}$ Second, at the time of ratification of the Draft Protocol or thereafter the state must have made a declaration accepting the jurisdiction of the Court to hear such cases. ${ }^{89}$

While limiting the access of NGOs and individuals to the Court may have been necessary to get states on board, ${ }^{90}$ it is nevertheless disappointing and a terrible blow to the standing and reputation of the Court in the eyes of most Africans. After all, it is individuals and NGOs, and not the African Commission, regional intergovernmental organizations, or state parties, who will be the primary beneficiaries and users of the Court. The proposed Court is not meant to be an institution for the protection of the rights of states or OAU organs. A human rights court is primarily a forum for protecting citizens against the state and other state agencies. This limitation will render the proposed Court virtually meaningless unless it is interpreted broadly and liberally.

The Court will be technically independent of the African Commission although it may request the Commission's opinion with respect to the admissibility of a case brought by an individual or an NGO. ${ }^{91}$ In ruling on the admissibility of a case, the Court will also be required to take into account the requirements that communications must meet under the African Charter before submission to the Commission. ${ }^{92}$ Presumably, the Court will not hear cases that do not meet these criteria. The Court may also consider cases or transfer them to the African Commission. ${ }^{93}$

87. See id. arts. 5(1), 5(2).

88. See id. art. 5(3) (providing that the "[c]ourt may entitle relevant Non Governmental Organizations (NGOs) with observer status before the [African] Commission, and individuals to institute cases directly before $\mathrm{it}^{\prime \prime}$ ) (emphasis added).

89. See id. arts. 5(3), 34(6).

90. Ambassador Badawi, a member of the African Commission and its former chair, alludes to this when he notes that "[t]he question of allowing NGOs and individuals to submit cases to the Court was one of the most complicated issues during the consideration of the Draft Protocol." Badawi El-Sheikh, supra note 68, at 947.

91. See Protocol, supra note 1, art. 6(1).

92. See id. art. 6(2). See African Charter, supra note 4, art. 56, for a list of the requirements that communications before the African Commission must consider it.

93. See Protocol, supra note 1 , art. 6(3). 
While linked to the Commission it is vital that the Court determines its own rules of procedure in order to enhance its independence. The Protocol provides some general rules of procedure. ${ }^{94}$ In addition, the Protocol provides that proceedings before the Court generally should be conducted in public and that parties will be entitled to legal representation of their own choice. ${ }^{95}$ As well, witnesses or parties to a case "shall enjoy all protection and facilities, in accordance with international law"96 in connection with their appearance before the Court. This guarantee will shield witnesses from various pressures and intimidation and facilitate their ability to participate more fully and freely in proceedings.

The proposed Court would be composed of eleven judges elected in their individual capacity by the OAU Assembly of Heads of States and Government from among "jurists of high moral character and of recognized practical, judicial or academic competence and experience in the field of human and peoples' rights. ${ }^{\prime \prime 7}$ Judges would serve for a six-year term and be eligible for re-election only once..$^{98}$ it is a shortcoming that all judges, except the President of the Court, would only serve on a part-time basis. ${ }^{99}$ Although the judges' independence would be formally guaranteed and they would be protected by diplomatic immunity under international law, ${ }^{100}$ the fact that the judges are only in part-time service would undermine the integrity and independence of the Court. A judge may only be removed by the unanimous decision of all the other judges of the Court. ${ }^{101} \mathrm{~A}$ judge who is a national of a state party to a case must be recused to avoid bias. ${ }^{102}$ It is an important consideration that the Court appoints its own registrar and registry staff. ${ }^{103}$

The proposed Court is given wide powers in conducting proceedings. It seems to have discretionary jurisdiction and need not take all the cases that come before it. ${ }^{104}$ This should allow the Court to avoid overload and to hear only those cases that have the potential to advance human rights protection in a meaningful way. If the Court does decide to hear a case, the Court may hear submissions from all parties, including oral, written, and expert

94. See id. art. 33.

95. See id. art. 10(1),(2). Free legal representation may also be provided where the "interests of justice so require." Id. art. 10(2).

96. Id. art. 10(3).

97. Id. art. 11(1).

98. See id. art. 15 (1).

99. See id. art. 15(4).

100. See id. art. 17.

101. See id. art. 19.

102. See id. art. 22.

103. See id. art. 24.

104. See Protocol, supra note 1, art. 3(2). 
testimony. ${ }^{105}$ States are required to assist the Court and provide facilities for the efficient handling of cases. ${ }^{106}$ Once the Court finds a violation, it may order remedies, including "fair compensation or reparation." ${ }^{107}$ In cases of "extreme gravity and urgency," the Court may order provisional remedies, such as an injunction, to avoid actual or potential irreparable harm to victims. ${ }^{108}$

The Court's judgments, which will be final and without appeal, ${ }^{109}$ will be binding on states. ${ }^{110}$ In its annual report to the OAU, the Court is to list specifically those states that have not complied with its judgments. ${ }^{111}$ This is a "shaming" tactic that marks the violator. The OAU Council of Ministers is required to monitor the execution of the judgment on behalf of the OAU Assembly. ${ }^{112}$ Presumably the OAU Assembly can take additional measures to force compliance, such as passing resolutions urging states to respect the Court's judgments. Alternatively, the OAU Chairman could be empowered to write to delinquent states asking that they honor the Court's judgments.

\section{WHAT SHOULD THE HUMAN RIGHTS COURT DO?}

Critics and supporters alike have argued that it makes little sense to create an institution that duplicates the weaknesses of the African Commission. In the context of the OAU, an organization with scarce financial resources and limited moral clarity and vision, the establishment of a new body should be approached somberly. A human rights court will only be useful if it genuinely seeks to correct the shortcomings of the African human rights system and provides victims of human rights violations with a real and accessible forum in which to vindicate their basic rights. What the OAU and the African regional system do not need is yet another remote and opaque bureaucracy that promises little and delivers nothing. If the Court is to be such a bureaucracy, then it would make more sense to expend additional resources and energy to address the problems of the African Commission and defer the establishment of a court for another day. Several important

105. See id. art. 26.

106. See id. art. 26(1).

107. Id. art. $27(1)$.

108. Id. art. $27(2)$.

109. See id. art. 28(2).

110. See id. art. 30 (providing, in part, that states "undertake to comply with the judgment in any case in which they are parties within the time stipulated by the Court and to guarantee its execution") (emphasis added).

111. See id. art. 31.

112. See id. art. 29(1). 
questions will have to be addressed if the Human Rights Court is to become a significant player in human rights in Africa.

The most pressing issues facing the new Court are normative and institutional. These issues require the Charter's amendment and revision. First, the African Charter, the Court's basic instrument, has deep normative flaws that must be addressed to give the Court a firm legal basis to protect human rights. In particular, "clawback" clauses permeate the African Charter and permit African states to restrict basic human rights to the maximum extent allowed by domestic law. ${ }^{113}$ This is especially significant because most domestic laws in Africa date from the colonial period and are therefore highly repressive and draconian. The post-colonial state, like its predecessor, impermissibly restricts most civil and political rights, particularly those pertaining to political participation, free expression, association and assembly, movement, and conscience. Ironically, it is these same rights that the African Charter further erodes.

'Clawback' clauses, that is, qualifications or limitations, permeate the provisions [of the African Charter] dealing with fundamental freedoms . . . . These fundamental civil and political rights are severely limited by clauses like 'except for reasons and conditions previously laid down by law,' 'subject to law and order,' 'within the law,' 'abides by the law,' 'in accordance with the provisions of the law, and other restrictions justified for the 'protection of national security.'114

The African Charter also lacks a general derogation clause, which appears to be unnecessary because states are in effect permitted by the "clawback" clauses to suspend, de facto, certain rights by enacting legislation..$^{115}$ In any event, nothing in the Charter prevents African states from denying certain rights during national "emergencies."116 A revision of the Charter should excise the offending "clawback" clauses, insert a provision on nonderogable rights, and another specifying which rights states can derogate from, when, and under what conditions.

Another area of normative controversy concerns women's rights. There is a perception and fear that either the African Charter does not adequately protect, or it could be used to abuse, women's rights. ${ }^{117}$ Of particular

113. See Mutua, supra note 10 , at 7 .

114. Id. at 7.

115. See Arthur E. Anthony, Beyond the Paper Tiger: The Challenge of a Human Rights Court in Africa, 32 TEx. INr'L L.J. 511, 518 (1997).

116. BUERGENTHAL, supra note 19 , at 233-34.

117. For discussions of the African Charter's view on women, see Claude E. Welch, Jr., Human Rights and African Women: A Comparison of Protection under Two Major Treaties, 15 Hum. Rrs. Q. 549 (1993); Florence Butegwa, Using the African Charter on Human and Peoples' Rights to Secure Women's Access to Land in Africa, in Human 
concern are the "family" provisions that have been thought to condone and support repressive and retrogressive structures and practices of social and political ordering. ${ }^{118}$ These provisions, which place duties to the family on the state and individuals, have been interpreted as entrenching oppressive family structures that marginalize and exclude women from participation in most spheres outside the home. Others feel that the provisions support the discriminatory treatment of women on the basis of gender in marriage, property ownership, and inheritance, and impose on them unconscionable labor and reproductive burdens. But, as this article has argued elsewhere, the Charter can be read differently:

However, these are not the practices that the Charter condones when it requires states to assist families as the 'custodians of morals and traditional values.' Such an interpretation would be a cynical misreading of the Charter. The reference is to those traditional values which enhanced the dignity of the individual and emphasized the dignity of motherhood and the importance of the female as the central link in the reproductive chain; women were highly valued as equals in the process of the regeneration of life. ${ }^{119}$

The Charter's veneration of African culture could be construed as reinforcing gender oppression. ${ }^{120}$ The charge here is that the Charter sees itself as the savior of an African culture that is permanent, static, and unchanging. Viewed this way, the Charter would freeze in time and protect from reform, radical change, or repudiation of those cultural norms, practices, and institutions that are harmful to women. Again, this article argues that the Charter, taken in its totality as a human rights document, does not support such a reading.

The Charter guarantees, unambiguously and without equivocation, the equal rights of women in its gender and equality provision by requiring states to

Rights of Women: National and International Perspectives 495 (Rebecca Cook ed., 1994); Chaloka Beyani, Toward a More Effective Guarantee of Women's Rights in the African Human Rights System, in Human Rights of Women: National and International Perspectives 285 (Rebecca Cook, ed. 1994; ). Oloka-Onyango, The Plight of the Larger Half: Human Rights, Gender Violence and the Legal Status of Refugee and Internally Displaced Women in Africa, 24 Denv. J. INr'L L. \& PoL'y 349, 371-74 (1996).

118. See African Charter, supra note 4, art. 18 (referring to the family as the "natural unit and basis of society" and requiring the state to "assist the family which is the custodian of morals and traditional values recognized by the community"). Elsewhere, the Charter provides that the individual owes "duties towards his family and society." Id. art. 27(1). Further, the African Charter states that every individual has the duty to "preserve the harmonious development of the family and to work for the cohesion and respect of the family; to respect his parents at all times, to maintain them in case of need." Id. art. 29(1).

119. See Mutua, supra note 8 , at $371-72$ (footnote omitted).

120. See id. at 371 . 
"eliminate every discrimination against women" and to protect women's rights in international human rights instruments. Read in conjunction with other provisions, the Charter leaves no room for discriminatory treatment against women. ${ }^{121}$

To allay these fears, however, and to prevent a conservative human rights court from ever giving the Charter a discriminatory interpretation in gender matters, the African Charter should be supplemented by an optional protocol to fully address women's rights issues in all their complexity and multiple dimensions. ${ }^{122}$

Besides the normative set of problems that face the Human Rights Court, there are also institutional problems. These concerns are external to the Court and are compounded by matters internal to it, such as the tenure of judges and its effect on the independence of the Court and the limitation of access to the Court to individuals and NGOs. In addition, it is absolutely critical that the Court be, and be perceived as, separate and independent from the African Commission to avoid burdening it with the severe image problems and the anemia associated with its older sibling. This is possible if there is a clear division of labor between the African Human Rights Court and the African Commission. That is not currently the case. A court was not contemplated by the drafters of the African Charter, and as a result, the African Commission was vested with both promotional and protective functions, such as the individual complaint procedure, which make the Commission "court-like" because of their quasi-judicial character.

To address this institutional concern, the African Charter should be revised. The protective functions of the African Commission should be removed and vested exclusively within the African Human Rights Court. The African Commission should only be charged with promotional functions including the monitoring of state reporting and the facilitating of dialogue with NGOs and government institutions in member states to encourage the incorporation of human rights norms into state policies and

121. See Mutua, supra note 10 , at $\mathbf{3 7 2}$ (footnote omitted). The Charter states that the "state shall ensure the elimination of every discrimination against women and also ensure the protection of the rights of the woman and the child as stipulated in international declarations and conventions." African Charter, supra note 4, art. 18(3). The Convention on the Elimination of All Forms of Discrimination Against Women (CEDAW) is among the international conventions that would be applicable here. Convention on the Elimination of All Forms of Discrimination Against Women, adopted 18 Dec. 1979, G.A. Res. 34/180, U.N. GOAR, 34th Sess., Supp. No. 46, U.N. Doc. A/34/36 (1980) (entered into force 3 Sept. 1981), reprinted in 19 I.L.M. 33 (1980). Normatively, the CEDAW is perceived as a very progressive and forward-looking document.

122. There already have been calls for a protocol on women's rights. See Murray, supra note 48 , at $16,19$. 
domestic legislation. ${ }^{123}$ This unambiguous demarcation of areas of competence should alleviate the problem of hierarchy or "competition" between the two institutions, and may enhance cooperation and mutual reinforcement. Importantly, such a division of labor should prevent tainting one body with the baggage of the other. Thus the African Commission would clearly be the "political" body, while the Court would alone be the judicial or "legal" organ of the African human rights system.

As the sole adjudicatory body in the African legal system, the African Court must consider the three basic purposes that are associated with national and international adjudicatory bodies: 1 ) vindicating the rule of law by providing justice in an individual case; 2 ) protecting rights through deterrence and behavior modification; and 3) expounding legal instruments and making law through elucidation and interpretation. ${ }^{124}$ To fulfill its promise, the African Human Rights Court will have to reflect carefully on these roles and decide where it has the potential to make a meaningful contribution.

While the African Human Rights Court should primarily be a forum for protecting citizens against the state, it should not be viewed as a forum for offering individual justice to victims of human rights violations. While such a goal is certainly noble, it is by all means impossible. The Court can act neither as a forum of first instance nor as the mandatory court of appeal for all cases. Cast in this role, the Court would be paralyzed by a torrential caseload. The most poignant example that warns of this potential paralysis is the Human Rights Committee (HRC), the body that oversees the implementation of the International Covenant on Civil and Political Rights. ${ }^{125}$ Under the Optional Protocol to the ICCPR, individuals can petition the HRC for the vindication of their rights. ${ }^{126}$ The HRC's use of a mandatory jurisdiction to consider all admissible cases has created at least three years of backlog. ${ }^{127}$ The possible ratification of the Optional Protocol by states with

123. At a recent meeting, NGOs and members of the African Commission started a dialogue on possible amendments and revisions to the African Charter. These included women's rights, "clawback" clauses, and derogation of rights. See id. at 19.

124. See Henry J. Steiner, Individual Claims in a World of Massive Violations: What Role for the Human Rights Committee?, in The Future of UN Human Rights Treaty Monitoring (Philip Alston \& James Crawford eds., forthcoming 1999) (see text at the beginning of section entitled "Purposes of Adjudication").

125. ICCPR, supra note 21 .

126. Optional Protocol to the International Covenant on Civil and Political Rights, adopted 16 Dec. 1966, G.A. Res. 2200A (XXI), U.N. GAOR, 21 Sess., Supp. No. 16, at arts. 1, 2, U.N. Doc. AV6316 (1966), 999 U.N.T.S. 171 (entered into force 23 Mar. 1976), reprinted in 6 I.L.M. 383 (1967).

127. For statistics on the twenty years since the HRC communications procedure became effective under the Optional Protocol, see Report of the Human Rights Committee to the General Assembly: Official Records, U.N.GAOR, 52nd Sess., Supp. No. 40, section VII(A), at 74, U.N. Doc A/52/40, Vol.I (1997). 
large populations such as China, India, the United States, and Indonesiatogether with the growing familiarity by victims with the procedure-can only underscore the complete inability of the HRC to respond to all individual cases.

The African Human Rights Court need not make the mistake of the HRC. It will not survive if it adopts a mandatory jurisdiction because the volume of cases is bound to be enormous. Instead the Court should only hear those cases that have the potential to expound on the African Charter and make law that would guide African states in developing legal and political cultures that respect human rights. In other words, the Court should not be concerned with individual cases where it looks, as it were, backwards, attempting to correct or punish a historical wrong to an individual. Rather, the Court should look forward and create a body of law with precedential value and an interpretation of the substantive law of the African Charter and other key universal human rights documents to guide and direct states. Such forward-looking decisions would deter states from future misconduct by modifying their behavior. Individual justice would be a coincidence in the few cases the Court would hear. Moreover, individual courts in OAU member states should look to the African Human Rights Court for direction in the development and application of human rights law.

Finally, the African Human Rights Court would benefit tremendously from the experiences of the European Court of Human Rights (ECHR) and the Inter-American Court of Human Rights as well as national fora such as the Constitutional Court of South Africa, which have taken the lead in developing human rights jurisprudence. The Court should closely examine the factors that have made these institutions effective. Some authors have identified a checklist of such factors that the African Human Rights Court ought to contemplate. ${ }^{128}$ For example, Helfer and Slaughter have organized these factors into three clusters: 1) factors that state parties to the treaty creating the Court control (such as the tribunal's composition, its investigative powers, and the legal status of its decisions); 2) factors that the tribunal itself controls such as quality of legal reasoning and degrees of autonomy from political interests; and 3) factors beyond the control of the tribunal and the state parties such as the cultural identities of states and the nature of abuses monitored by the tribunals. ${ }^{129}$ This checklist can be particularly useful if judges are independent and motivated by the drive to make the African Human Rights Court the central institution in the development of a legal culture based on the rule of law.

128. See generally Laurence R. Helfer \& Anne-Marie Slaughter, Toward a Theory of Effective Supranational Adjudication, 107 YALE L.J. 273, 298-337 (1997).

129. Id. at 298-337. 


\section{CONCLUSION}

Africa has been traumatized by human rights violations over the last five centuries. The recent chapter in that long history of abuses is still being authored under the direction of the post-colonial state. But the peoples of Africa, like peoples elsewhere, have never stopped struggling for better conditions of life, and especially for more enlightened and accountable political societies. The popular repudiation of one-party and undemocratic states over the past decade has once again given hope that the predatory impulses of the post-colonial state can be arrested. Within states, NGOs have multiplied during the last ten years, and governments have been forced to revise policies and laws that are offensive to basic human rights. At the continental level, NGOs and human rights advocates have demanded that the African Commission become part of this movement toward change.

It is in this context that the idea of an African Human Rights Court was hatched. It was felt by many Africans that, while the African Commission was a step in the right direction, it was largely ineffectual. A regional human rights system worth its name needed strong institutions to anchor its norms. The African Human Rights Court is an attempt to fill this void. However, the Court promises to be a disappointment unless state parties revisit the African Charter and strengthen many of its substantive provisions. Moreover, the Court will not meet the expectations of Africans if the OAU does not provide it with material and moral support to allow it to function as the independent and significant institution that it ought to be. Finally, the initial integrity and vitality of the Court will rest with those who will be privileged to serve as its first bench. Unless these conditions are met, the African Human Rights Court is condemned to remain a two-legged stool, a lame institution unable to fulfill its promise as a seat from which human rights can be effectively protected and advanced. 